\title{
AMERICAN TRYPANOSOMIASIS (CHAGAS' DISEASE) IN CONVENTIONAL AND GERMFREE RATS AND MICE (1)
}

Marcelo E. SILVA (2), Elizio A. EVANGELISTA (3), Jacques R. NICOLI (3), Eduardo A. BAMBIRRA (4) \& Enio C. VIEIRA (3)

Germfree (GF) and conventional (CV) CFW (LOB) mice and Wistar and SpragueDawley rats were infected with Trypanosoma cruzi. The disease was more severe in the GF than in the CV animals as revealed by: (1) an earlier and more intense parasitemia; (2) a more precocious mortality; (3) a twice enlarged spleen: (4) a more intense cell and tissue parasitism; (5) visceral signs of cardiac failure.

KEY WORDS: Chagas' disease; Trypanosomiasis; Germfree rats; Germfree mice.

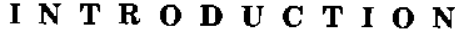

The difference between germfree (GF) and conventional (CV) animals of the same species is not restricted to the absence of the normal flora in the former. To this characteristics, the lack of reaction of the host to germs and a series of direct effects of these germs on the host should be added (GORDON \& PESTI, 1971).

GF animals, when infected with pathogens may exhibit higher or lower resistance to the infecting organism (GORDON \& PESTI, 1971; PLEASANTS, 1974). GF mice are five times more resistant and show more intense mitogenie and immunogenic responses to bacterial endotoxins than their $\mathrm{CV}$ counterparts (KIYONO et al., 1980). FINERTY et al. (1972) infected GF and CV mice with Plasmodium herghei; the rise in parasitemia was more precocious in CV animals even although antibodies could be detected ear- lier in GF mice which also had higher plasma immunoglobulin titers. On infection with Epery throzoon coccoides, $C V$ reacted more efficiently than GF mice.(HYDE et al., 1972). VIEIR A et al., (1985) presented preliminary evidences that schistosomiasis mansoni was less severe in GF than in cV mice.

In the present work, the infection with Trypanosoma cruzi was studied in $\mathrm{GF}$ and $\mathrm{CV}$ mice and rats.

\section{MATERIAL AND METHODS}

Colombian and $\mathrm{Y}$ strains of $\mathrm{T}$. cruzi were maintained in $\mathrm{CV}$ mice and in irradiated $\mathrm{CV}$ rats. To obtain the inocula, the animals were killed under ether anesthesia. Blood was collected from the axillary plexus of mice or directly from the

(1) This work was extracted from the M. S. thesis of MES.

(2) Present address: Departamento de Nutriçăo, Escola de Farmácia, Universidade Federal de Ouro Preto, Ouro Preto, MG. Brasil.

(3) Departamento de Bioquímica-Imunologia, Instituto de Ciências Biológicas, Universidade Federal de Minas Gerais (UFMG), Belo Horizonte, MG., Brasil.

(4) Departamento de Anatomia Patológica, Faculdade de Medicina, UFMG, Belo Horizonte, MG., Brasil. 
heart of rats with syringes containing heparin. The evaluation of the number of trypomastigotes was done according to BRENER (1962). The adjustment of the number of parasites to the desired inocula was done by dilution with blood obtained from uninfected animals. The manipulations were performed in a laminar flow hood. The blood was transferred to sterile ampoules. A sample was seeded in thioglycollate medium and brain-heart broth for control of asepsis. The ampoules were then sealed in a flame and introduced into the isolator. Contamination was never detected in the control samples after incubation at $28^{\circ} \mathrm{C}$ and $37^{\circ} \mathrm{C}$.

Breeding nuclei of GF (LOB) mice and GF Wistar rats were supplied by Dr. Morris Pollard, University of Notre Dame, Notre Dame, Indiana, USA. A breeding nucleus of GF Sprague-Dawley rats was obtained from Dr. Edward Balish, University of Wisconsin, Madison, Wisconsin, USA. Those animals are free of all demonstrable microbes. Mice, however, bear a leukemogenic virus acquired prenatally which remains latent unless activated by radiation (POLLARD, 1965).

The $\mathrm{CV}$ animals were derived from the GF colony. Rats and mice support very well the conventionalization.

GF rats and mice were maintained in flexible plastic isolators (TREXLER, 1959) and manipulated according to established procedures (PLEASANTS, 1974). Unless otherwise stated, the $C V$ counterparts were also main tained in isolators and handled accordingly.

GF and CV 21 and 56 days old Wistar rats and 14 months old Sprague-Dawley rats were inoculated intraperitoneally (i. p.) with $10^{5}$ trypo: mastigotes per gram of body weight of Colom. bian strain of T. cruzi. GF and CV three months old CFW (LOB) mice were inoculated i. p. with $8 \times 10^{4}$ trypomastigotes of $\mathrm{Y}$ strain of $\mathbf{T}$. cruzi. GF and CV 21 days old CFW (LOB) mice were inoculated similarly with $1.0-1.3 \times 10^{4}$ trypomastigotes of $\mathrm{Y}$ strain of $\mathbf{T}$. cruzi.

Blood trypomastigotes were counted daily, as described by BRENER (1962).

The experiment was run until the death of the animals. In experiments with rats, some ani- mals were killed under ether anesthesia. The animals were opened ventrally from the neck to the end of the abdomen and immersed in $4 \%$ formaldehyde solution. Fragments measuring $2-4 \mathrm{~mm}$ were removed from the thymus, liver, spleen, lymphonodes, brain, and skeletal, cardiac, and smooth muscles. The fragments were fixed in $4 \%$ formaldehyde solution and processed for paraffin embedding. The sections were stained with hematoxylin-eosin. The slides were examined by only one person who did not have access to the codification of the slides, whose identification was done only after each report had already been written.

The control of isolator asepsis was done according to WAGNER (1959).

\section{RESULTS}

Mice

Figure 1 shows the evolution of the parasitemia and the cumulative mortality of six GF and four $\mathrm{CV}$ three months old male CFW mice infected with $8 \times 10^{4}$ blood forms of trypomastigotes of T. cruzi, $Y$ strain. An earlier and more intense

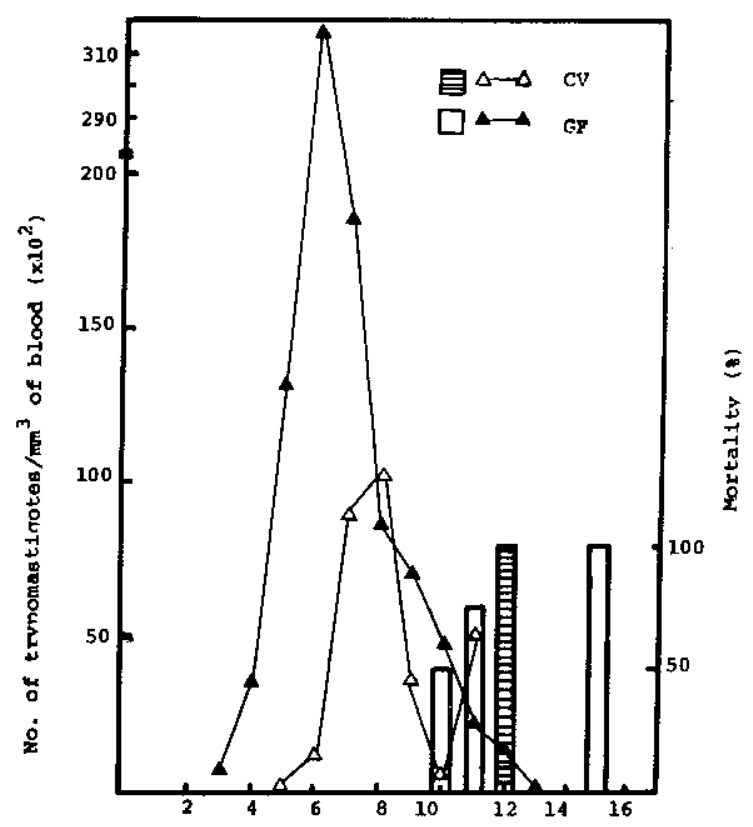

Fig. 1 - Parasitemia and cumulative mortality in groups of germfree $(G F)^{6}$ and conventional $(C V)^{4}$ three months old CFW mice inoculated with $8 \times 10^{4}$ blood forms of Trypanosoma cruzi, Y strain. 
parasitemia was observed in the GF group. The mortality aIso was more precocious in the GF than in CV group, even though two GF animals survived up to the $15^{\text {th }}$ day after infection. At the $12^{\text {th }}$ day, all CV and $66 \%$ of the GF animals were dead.

The experiment was repeated with four male and five female GF and six male and twelve female $\mathrm{CV}, 21$ days old mice infected with 1.0-1.3 x $10^{4}$ trypomastigotes of $Y$ strain of $\mathbf{T}$. cruzi. Again, both parasitemia and mortality were more precocious in the GF group, although the peak of parasitemia was higher in CV mice. In this experiment, the $\mathrm{CV}$ animals were kept in the $\mathrm{CV}$ animal room. After the beginning of the experiment, there was a drop in the temperature that affected mostly the CV mice.

\section{Rats}

A preliminary experiment with one female and one male GF and two female CV 14 months old Sprague-Dawley rats was carried out. A higher parasitemia and a more precocious death were observed in GF group.

Figure 2 shows the parasitemia and the mortality of five GF and six CV Wistar male 21 days

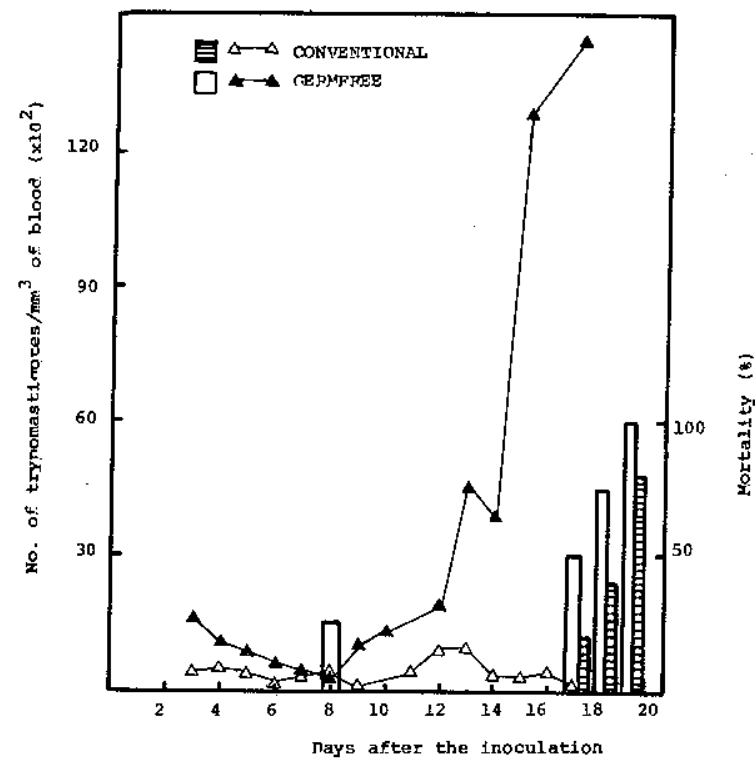

Fig. 2 - Parasitemia and cumulative mortality of germfree ${ }^{5}$ and conventional ${ }^{6}$ days old Wistar male rats weighing $60 \mathrm{~g}$, inoculated with $6 \times 10^{\mathrm{a}}$ blood forms of $U$ strain of Trypanosoma cruzi. old rats weighing approximately $60 \mathrm{~g}$ and inoculated with $6 \times 10^{6}$ trypomastigotes of Colombian strain of T. cruzi. The parasitemia was much higher in the GF group reaching 150.000 trypomastigotes $/ \mathrm{mm}^{3}$ of blood. The mortality was also more precocious in the GF group. At the $21^{\text {st }}$ day, all GF had died whereas one CV lived up to the $47^{\text {th }}$ day, when it was sacrificed.

The histopathological findings were similar in rats and mice from the above mentioned groups. Macroscopically: (1) the spleens from GF animals were twice the size of CV animals; (2) pronounced signs of congestive cardiac insufficiency (such as, ascites and generalized viscera] congestion) in GF animals. Microscopically: (1) more intense cell and tissue parasitism in GF than in $\mathrm{CV}$ animals; (2) the parasitism was much more intense in the organs rich in cells of the mononuclear phagocytic system and in the parenchyma of liver, adrenals and muscles (cardiac, skeletal and smooth) of both GF and CV animals. In the central nervous system, there were sparse and discrete infiammatory lesions and cellular parasitism.

Figure 3 shows a sample of the histopathologic findings in hearts of GF and CV mice. The more intense agressiveness of the disease in GF animals is evident.

The experiment was repeated with four male and four female GF and three male and three female $\mathrm{CV}, 56$ days old Wistar rats weighing approximately $110 \mathrm{~g}$. The animals were inoculated with $12 \times 10^{6}$ trypomastigotes of Colombian strain of $\mathbf{T}$. cruzi. The parasitemia was more precocious and higher in the GF groups. All animals survived to the $71^{\text {st }}$ day, when they were killed.

On histopathological examination, no difference between the $\mathrm{GF}$ and the $\mathrm{CV}$ animals could be detected. A discrete focal parasitism in the muscular and macrophagic phagocytic system could be visualized.

\section{DISCUSSION}

Mice are the animals most widely used as hosts in experimental Chagas' disease. They develop an acute and a chronic phase following infection with T. cruzi. Figure 1 shows that GF 
SILVA. M. E.: EVANGELISTA. E. A.: NICOLI. J. R.: BAMBIRRA. E. A. \& VIEIRA. E. C. - American trypanosomiasis , Chagas disease? in conventional and germfree rats and mice. Rev. Inst. Męd. trop. Sảo Paulo, 29:284.288. 1987.

mice had an earlier and higher parasitemia than their CV counterparts. These results may be explained by the fact that GF mice have a less developed lymphoid system when compared with $\mathrm{CV}$ mice, impairing the cell-mediated immune response (SZERI et al., 1976). ROGERS \& BALISH (1978) and GOODMAN et al. (1978) reported evidences for the "immunological immaturity" of GF animals. The rate of gamma-
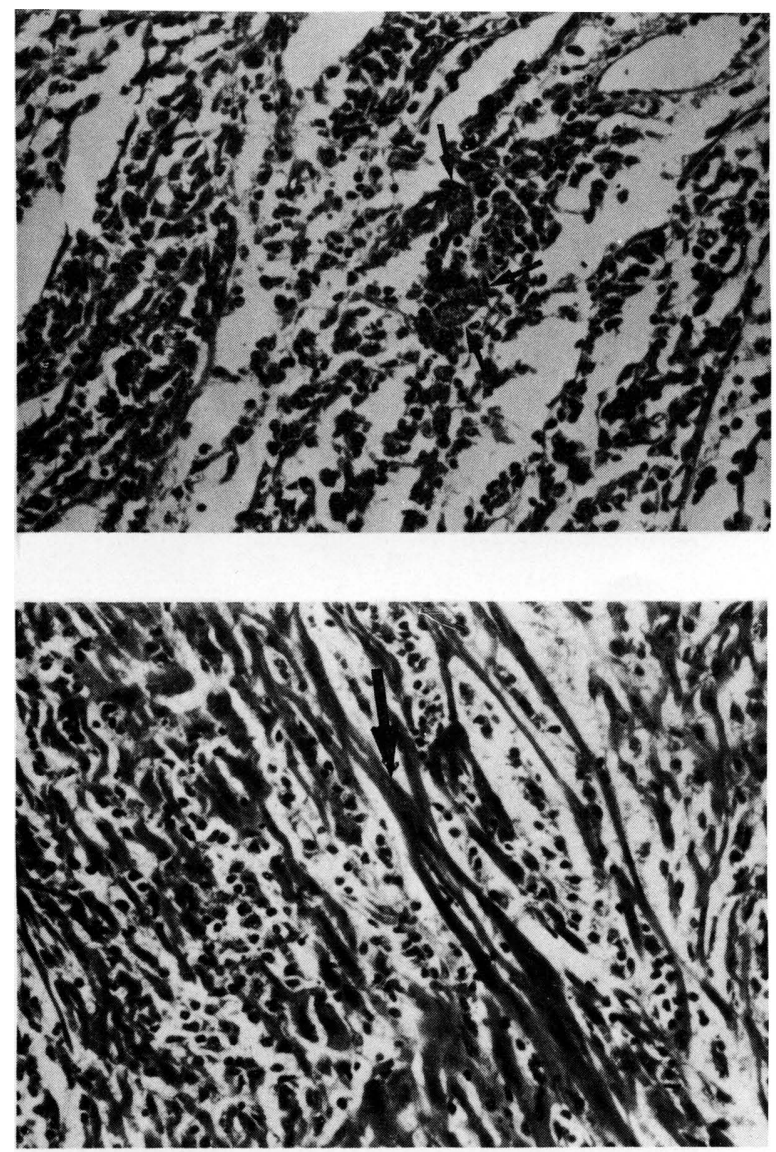

Fig. 3 - Histopathologic aspect of the heart of three months old germfree (A) and conventional (B) CFW mice. A: cellular parasitism (arrows) and intense edema dissociating the myocardial fibers. Mononuclear inflammatory cells are admixed with degenerated and dissociated fibers. B: cellular parasitism (arrow) and diffuse mononuclear inflammatory infiltration and interstitial edema. The less agressive inflammatory process in the myocardium of conventional mice can be observed (hema toxylin and eosin X320).

globulin synthesis is 50 times higher in $\mathrm{CV}$ than in GF mice (SELL \& FAHEY, 1964). These data are also suggestive of a slower humoral immune response in $\mathrm{GF}$ than in $\mathrm{CV}$ mice. The histopathological data confirm that the disease is much more severe in the GF group (Fig. 3). The higher cell and tissue parasitism in GF mice may be explained by the smaller number of cells invol ved in immunological defense such as:'lymphocytes (OLSON \& WOSTMAN, 1966a) and neutrophils, monocytes, and eosinophils IOLSON \& WOSTMANN, 1966b).

Moreover peritoneal macrophages from GF mice are possibly less activated than those obtained from $\mathrm{CV}$ animals. Macrophages from $\mathrm{GF}$ animals have smaller and more spherical nuclei, fewer mitochondria and a higher number of lysosome-like granules per unit volume of cytoplasm (WOODWARD, 1978). These differences may be possibly related to the lack of stimuli from in testinal flora (WOODWARD, 1978).

The higher parasitemia found in $\mathrm{CV}$ mice in the second experiment might be explained by the lower temperature of the room where the animals were housed. It is well known that there is a raise in parasitemia at lower temperatures (KOLODNY, 1940). Nevertheless. the death rate and the histopathological findings confirmed the results of the first experiment.

Figure 2 shows that, in rats, the levels of parasitemia were higher in the GF than in CV group. In 21 days old animals, the mortality was earlier and total in the GF group. All six GF and four out five $\mathrm{CV}$ rats died. The high mortality of young rats infected with $\mathbf{T}$. cruzi confirms the results of KOLODNY (1940) and CULBERTSON \& KESSLER (1942), who showed that the disease is more severe in younger animals. The morphological findings are compatible with the parasitological data, i. e., the disease was more severe in $\mathrm{GF}$ than in $\mathrm{CV}$ rats.

In older rats there was no mortality in either group of animals. The parasitemia, again, was more precocious and higher in the GF than in the $\mathrm{CV}$ rats. The histopathological findings were similar for both groups.

The results reported herein show that Chagas' disease is more severe in $\mathrm{GF}$ than in $\mathrm{CV}$ rats and mice. Further work will be carried out to elucidate the reason for the observed differences. 
SILVA, M. E.; EVANGELISTA, E. A.: NICOLI, J. R.; BAMBIRRA, E. A. \& VIEIRA. E. C. - American trypanosomiasis ‘Chagas' disease) in conventional and germfree rats and mice. Rev. Inst. Med. trop. Sáo Paulo, 29:284-288, 1987.

\section{RESUMO}

Tripanosomiase americana (doença de Chagas) em ratos e camundongos convencionais e isentos de germes

Camundongos CFW (LOB) e ratos Wistar e Sprague-Dawley isentos de germes (GF) e convencionais (CV) foram infectados com Trypanosoma cruzi. A doença foi mais grave nos animais GF do que nos CV, o que foi demonstrado por: (1) uma parasitemia mais precoce e mais intensa; (2) uma mortalidade mais precoce; (3) baço duas vezes maior; (4) um parasitismo celular e tissular mais intenso; (5) sinais viscerais de insuficiência cardíaca.

\section{ACKNOWLEDGEMENTS}

This work was supported by Financiadora de Estudos e Projetos (FINEP) and by Conselho Nacional de Desenvolvimento Científico e Tecnológico (CNPq). The technical help of Ronilda M. de Paula and Carlos Gomes Silva is acknowledged.

\section{REFERENCES}

1. BRENER, Z. - Therapeutic activity and criterion of cure on mice experimentally infected with Trypanosoma cruxi. Rev. Inst. Med. trop. S. Paulo, 4: 389-396, 1962.

2. CULBERTSON, J. T. \& KESSLER, W. R. - Age resistance of mice to Trypanosoma cruzi. J. Parasit., 28: $155-158,1942$.

3. FINERTY, J.F.; TOBIE, J. E. \& EVANS, C. B. - Antibody and immunoglobulin synthesis $\mathrm{m}$ germfree and conventional mice infected with Plasmodium bergbei, Amer, J. trop. Med. Hyg., 21: 499-505, 1972.

4. GOODMAN, M. G.; FIDLER, J. M. \& WEIGLE, W. O - Nonspecific activation of murine lymphocytes. II. Cells responding mitogenically to 2-mercaptoethanol are typical unstimulated lymphocytes. J. Immunol., 121: $1898-1904,1978$

5. GORDON, H. A. \& PESTI, L. - The gnotobiotic animal as a tool in the study of host-microbial relationship. Bact. Rev., 35: 390-429, 1971.

6. HYDE, C. L.; FINERTY, J. F. \& EVANS, C. B. - Antibody and immunoglobulin syrithesis in germfree and conventional mice infected with Epery throzoon coccoides. Amer. J. trop. Med. Hyg., 21: 506-511, 1972.

7. KIYONO, H.; MCGHEE, J. R. \& MICHALEK, S. M. LPS regulation of the immune response: comparison of res- ponse to LPS in germfree, Escherichia coli-monoassocia ted and conventional mice. J. Immunol., 124: 36-41, 1980.

8. KOLODNY, M. H. - Studies on age resistance against trypanosome infection. $I$. The resistance of rats of different ages to infection with T. cruxi. Amer. J. Hyg., 29: 13.24, 1939.

9. KOLODNY, M. H. - The effect of environmental temperature upon experimental trypanosomiasis (T. cruzi) of rats. Amer. J. Hyg., 32: 21-23, 1940.

10. OLSON, G. B. \& WOSTMANN, B. S. - Lymphocytopuiesis, plasmocytopoiesis and cellular proliferation in nonantigenicaliy stimulated germfree mice. J. Immunol., 97: 267-274, 1966a.

11. OLSON, G. B. \& WOSTMANN, B. S. - Cellular and humoral immune response of germfree mice stimulated with 75 HGGor Salmonella typhimurium. J. Immunol., 97: 275-286, 1966b.

12. PLEAsants, J. R. - Gnotobiotics. In: MELBY JR.; E. C. \& ALTMAN, N. H. ed. - Handbook of laboratory animal science. Cleveland, CRC Press, 1974. p. 119-174.

13. POLLARD, M. - Viral status of germfree mice. Natl. Cancer Inst. Monograph., 20: 167-172, 1965.

14. ROGERS, T. J. \& BALISH, E. - Effect of the systemic candidiasis on blastogenesis of lymphocytes from germfree and conventional rats. Infect. Immun., 20: 142-150, 1978.

15. SELL, S. \& FAHEY, J, L. - Relationship between $\boldsymbol{\gamma}$-globulin metabolism and low serum $\gamma$-globulin in germfree inice. J. Immunol., 93: 81-87, 1964.

16. SZERI, I.; ANDERLIK, P.; BANOS, Z. \& RADNAI, B - Decreased cellular response in germ-free animals. Acta Microbiol. Acad. Sci. hung., 23: 231-234, 1976.

17. TREXLER, P. C. - The use of plastics in the design of isolator systems. Ann. N. Y. Acad. Sci., 78: 29-36, 1959.

18. VIEIRA, L. Q.; MORAES E SANTOS, T. \& VIEIRA, E. C. - Alterations in cell number, size and collagen content in livers of conventional and germfree mice bearing Schis.

- tosoma mansoni. In: WOSTMANN, B. S., ed. --Germfree research: Microflora. Control and its application to the biomedical sciences. New Xork, Alan R. Liss, 1985. p. 235-238.

19. WAGNER, M. - Determination of germfree status. Ann. N. Y. Acad. Sci., 78: 89-101, 1959.

20. WOODWARD, B. - A stereological ultrastructural study of peritoneal macrophages from germfree and conventionally-reared mice. Cell Tiss. Res., 192: 157-166. 1978.

Recebido para publicação em 16/1/87. 